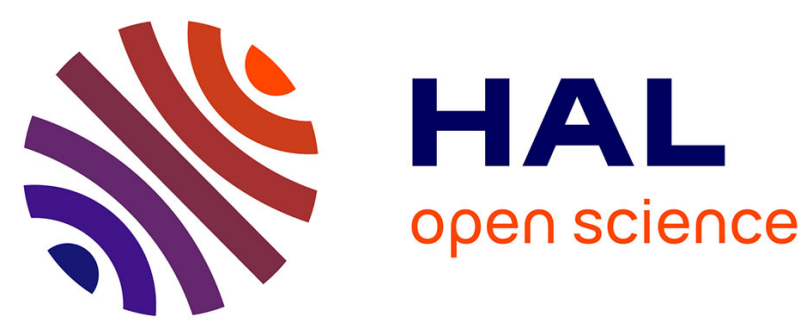

\title{
Le mythe normand chez Gerrard Winstanley: une conception populaire de l'identité nationale anglaise au cœur des années révolutionnaires
}

Luc Borot

\section{- To cite this version:}

Luc Borot. Le mythe normand chez Gerrard Winstanley: une conception populaire de l'identité nationale anglaise au cœur des années révolutionnaires. Bulletin de la Société d'Etudes AngloAméricaines des XVIIème et XVIIIème siècles, 1991, 32 (1), pp.7-20. 10.3406/xvii.1991.1192 . halshs01510855

\section{HAL Id: halshs-01510855 \\ https://shs.hal.science/halshs-01510855}

Submitted on 20 Apr 2017

HAL is a multi-disciplinary open access archive for the deposit and dissemination of scientific research documents, whether they are published or not. The documents may come from teaching and research institutions in France or abroad, or from public or private research centers.
L'archive ouverte pluridisciplinaire HAL, est destinée au dépôt et à la diffusion de documents scientifiques de niveau recherche, publiés ou non, émanant des établissements d'enseignement et de recherche français ou étrangers, des laboratoires publics ou privés. 


\section{Le mythe normand chez Gerrard Winstanley : une conception} populaire de l'identité nationale anglaise au cœur des années révolutionnaires

\section{Luc Borot}

\section{Citer ce document / Cite this document :}

Borot Luc. Le mythe normand chez Gerrard Winstanley : une conception populaire de l'identité nationale anglaise au cœur des années révolutionnaires. In: XVII-XVIII. Bulletin de la société d'études anglo-américaines des XVIle et XVIIle siècles. N³2, 1991. pp. 7-20;

doi : 10.3406/xvii.1991.1192

http://www.persee.fr/doc/xvii_0291-3798_1991_num_32_1_1192

Document généré le 24/05/2016 


\section{LE MYTHE NORMAND CHEZ GERRARD WINSTANLEY : UNE CONCEPTION POPULAIRE DE L'IDENTITE NATIONALE ANGLAISE AU CCEUR DES ANNÉES REVOLUTIONNAIRES}

Le parti Digger dans la Révolution anglaise, première du nom, fut peu entendu, resta peu nombreux, et demeure mal compris. ${ }^{1}$ Les historiens britanniques ont longtemps rangé ces «puritains» non cromwelliens dans la catégorie de la «lunatic fringe,» la marginalité cinglée, les simples d'esprit millénaristes, communalistes et nationalistes, ceux qui mélangeaient les mythes juridiques de la «common law» et la typologie eschatologique. Les écrits du Bêcheux Winstanley restèrent donc longtemps méprisés et rejetés. $^{2}$

L'historien des idées devrait ici se méfier : ne serait-il pas sur le point de surestimer les écrits d'un marginal peu connu de son vivant, et donc peu représentatif de ses contemporains? Une époque peut être définie autant par les hommes qu'elle rejette que par ceux qu'elle voit -ou fait - accéder aux honneurs. L'écrit du pauvre obscur, eût-il du talent comme Winstanley, ne pouvait être largement imprimé et diffusé en ces temps d'illettrisme, bien que les presses clandestines eussent été l'honneur et la liberté du peuple anglais sous l'oppression des évêques puis sous celle des presbytres.

La période d'activité de Gerrard Winstanley est relativement courte, si nous la mesurons par ses écrits qui furent publiés entre 1648 et 1651 , avec la période glorieuse des quelques mois de 1648-1650 durant lesquels il conduisit la communauté de Saint-George's Hill à Walton dans le Surrey. La typologie que les protestants anglais avaient déjà coutume d'appliquer à leur vie spirituelle privée comme à la vie de leurs Eglises, est appliquée par Winstanley à l'histoire des pauvres en Angleterre. Il fait porter cette méthode interprétative sur un corpus de références historiques et juridiques auxquelles il attache des valeurs symboliques permettant de fondre l'histoire sainte et l'histoire anglaise en une histoire sainte des pauvres d'Angleterre.

C'est cette rencontre syncrétique entre le nationalisme anglais mêlé au "patriotisme» ecclésial protestant, et le sentiment d'appartenance des pauvres ruraux expropriés à une catégorie sociale incarnant l'aventure politique et spirituelle du peuple anglais en révolte, qui fait de Winstanley le représentant le plus attachant et le plus pathétique de la mouvance radicale de cette révolution.

Je prends le concept d'identité dans un sens politique. Chez Winstanley, le discours sur l'identité porte sur l'identité sociale et sur l'identité spiri- 
tuelle, autant que sur l'identité nationale. Grâce au langage biblique sur les frères aînés et les frères cadets, il fait correspondre la taxinomie des groupes sociaux en Angleterre à une hiérarchisation spirituelle.

Je voudrais en effet attirer aujourd'hui l'attention sur deux éléments structurants du discours de Winstanley : sa version du mythe normand et son usage des expressions «elder brothers» et «younger brothers» pour désigner respectivement les riches et les pauvres. Ce n'est pas chez Winstanley qu'on trouve le plus souvent le terme «birthright,» mais c'est pourtant chez lui que le mythe biblique de Jacob et Esaü est le plus fécond. Je commencerai par un bref exposé des sens divers du terme «birthright,» accompagné d'une étude succincte du mythe de Jacob et Esaü, j'envisagerai ensuite le fonctionnement de l'idée de droit fondamental ou d'héritage dans la version du mythe normand proposée par Winstanley, puis je proposerai une interprétation de l'usage spécifique du mythe de Jacob et Esaü chez Winstanley. On verra alors comment Winstanley métamorphose le mythe national et patriotique du Joug Normand en un message universaliste.

\section{Le "birtbright," Jacob et Esaü : definitions}

Dans le Shorter OED : «1535. Right by birth; the rights, privileges, etc. to which one is entitled by birth. spec. The rights of the first born.» Deux exemples, «Sell me this day thy birthright» (Gen. 25.31), et une phrase de Coleridge : «The laws of the land are the birthright of every native.» J'organiserai donc ce premier point selon ce même plan : droit fondamental (qui est différent du droit de nature), droit d'héritage et droit d'aînesse.

Dans le langage des Niveleurs, qui est souvent d'inspiration juridique, le terme «birthright» désigne le droit de citoyenneté, qui leur est da parce qu'ils sont Anglais et qu'ils ont contribué à faire tomber le pouvoir royal de son piédestal. Lorsque les Agitateurs présents à Putney en 1647 réclamaient leur «birthright,» c'était un droit politique fondamental : témoin les termes du colonel Rainborough :

I desired that those that had engaged in it might be included. For really I think that the poorest he that is in England hath a life to live, as the greatest he ; and therefore truly, sir, I think it's clear, that every man that is to live under a government ought first by his own consent to put himself under that government; and I do think that the poorest man in England is not at all bound in a strict sense to that government that he hath not had a voice to put himself under ; and I am confident that, when I have heard the reasons against it, something will be said to answer those reasons, insomuch that I should doubt whether he was an Englishman or no, that should doubt of these things. ${ }^{3}$

Le chef puritain Ireton leur répond sur un tout autre registre, et définit un «birthright» minimal qui nie le sens de privilège natif national et militant que les Agitateurs entendaient donner à ce terme : 
Men may justly have by birthright by their very being born in England, that we should not seclude them out of England, that we should not refuse to give them air, and place and ground, and the freedom of the highways and other things (...). But that by a man's being born here he shall have a share in that power that shall dispose of the lands here, and of all things here, I do not think it a sufficient ground. ${ }^{4}$

Le droit civique ne peut se comprendre pour Ireton que comme le privilège de ceux qui possèdent un «fixed interest» dans le pays, ceux qui avaient déjà ce droit de choisir les membres des Communes dans le cadre de la constitution existante, soit les francs tenanciers de 40 shillings de revenu.

Quand il était utilisé par Lilburne ou Walwyn, ce terme de «birthright» désignait les droits fondamentaux des héritiers des «freeborn» AngloSaxons dépouillés par les envahisseurs normands. Je reviendrai sur ce thème un peu plus loin.

Le droit d'héritage et le droit d'aînesse sont définis par l'Ancien Testament principalement en deux endroits :

- Deut. 21.15 :

la Vulgate désigne le premier né par le terme de primogenitus, et les deux traductions anglaises que j'ai consultées, la Geneva Bible de 1560 et l'Autborised Version de 1611 parlent du "first born." La loi de Moïse déclare que les parents ne peuvent rien enlever au droit du premier né dans leur héritage. C'est au nom de ce principe que Jacob ne peut avoir droit à l'héritage de son père Isaac, malgré l'affection de sa mère, mais c'est aussi au nom de ce principe que sa mère lui conseille de tromper son père devenu aveugle pour lui voler la bénédiction due à Esaü.

- Genèse :

la Vulgate utilise le neutre pluriel primogenita là où les deux versions anglaises consultées parlent de «birthright.» La transgression d'Esaü est d'avoir préféré la satisfaction d'un besoin physique à un droit ordonné par Dieu, en vendant à Jacob son «birthright» contre un «pottage of lentiles» pour Genève, ou «a mess of pottage» pour l' $A V$. Esaü symbolise entre autres choses la soumission à la chair.

L'histoire des patriarches jumeaux revêt un caractère fondateur pour le Judaïsme, car l'un des deux devient Israël, le père des douze tribus, alors se l'autre est Edom, l'ennemi. C'est la répétition symbolique du meurtre Abel par Caïn, c'est la préfiguration de la lutte entre Saül et David, de la rupture entre le royaume du nord et celui du sud, de la division entre ceux qui suivront les pratiques idolâtres et le petit reste saint qui restera fidèle au Dieu unique.

Le premier né des deux jumeaux est Esaü, ce qui indique qu'il est le premier conçu. Dès le ventre maternel, les deux enfants semblaient se bat- 
tre, et une prophétie avait annoncé à leur mère qu'ils seraient les pères de deux grands peuples. L'affection des parents est divisée, et c'est l'aîné apparent qui est favorisé par son père pour la venaison qu'il sait préparer pour ses repas. C'est grâce à la faveur de sa mère que Jacob va retrouver le droit qui est le sien spirituellement. La vente de son droit par Esaü montre qu'il usurpait son droit. Des sources talmudiques rapportent qu'il devait avoir des rapports avec des femmes païennes avec qui il se livrait à des pratiques idolâtres.'

La tromperie de Jacob à l'égard d'Isaac répare donc une injustice qui donnait la prééminence d̀ celui qui était spirituellement déchu. Winstanley va sans cesse rappeler la nécessité de restituer au frère cadet ce à quoi il a droit du fait de sa faiblesse et de sa «righteousness» selon l'esprit.

\section{Droit fondamental, héritage et mythe normand}

La conquête de 1066 fait l'objet d'un mythe en Angleterre, et comme tous les grands mythes, le mythe normand est susceptible d'interprétations divergentes. Si l'on cherche à classer les tendances principales de ces interprétations, on peut dégager deux tendances, que je qualifierai rapidement et inadéquatement de tendances conservatrices et progressistes.

Pour les premières, Guillaume le Conquérant n'aurait fait que confirmer les privilèges des sujets anglo-saxons de son prédécesseur Edouard Ier, et c'est à la suite d'une omission de la part des souverains que la Grande Charte de 1215 est venue rappeler l'obligation pour les rois de convoquer des parlements à deux chambres pour fixer l'assiette et la nature des nouveaux impôts. Certaines terres ont été données aux officiers et aux soldats du conquérant, mais tous les Anglo-Saxons n'ont pas été réduits en esclavage. Pour Sir Edward Coke, si les tenures sont héritées de la distribution de Guillaume le Conquérant, on ne peut prétendre pour autant que les tenanciers actuels soient tous des héritiers directs des Normands. La coutume est chose changeante et les «manors» de son temps sont le résultat d'un processus d'évolution difficilement mesurable. Il soutient que les premières générations de «freeholders» et de «barons» allaient siéger au conseil du roi et que le Parlement d'alors avait deux chambres. ${ }^{6}$

Les visions progressistes de ce mythe prétendent que la conquête a provoqué l'expropriation des premiers occupants, et la prise de toutes les terres par les Normands. Les privilèges natifs des Anglo-Saxons (et c'est ici que Lilburne parle de «birthright») ont été aliénés, et la Grande Charte de 1215 qui les rappelait a été mise sous le boisseau par les progrès de la prérogative royale, que la révolution en cours doit mettre à bas. Pour un autre Niveleur, William Walwyn, les privilèges de la Grande Charte sont des confirmations d'avantages privés qui contribuent à opprimer le peuple anglais. Même les articles concernant le Parlement sont restrictifs, et les Parlements ont passé leur temps à additionner des privilèges et des monopoles. Walwyn 
suggère donc à Lilburne de prolonger la lutte du peuple anglais au-delà de la restauration de la Grande Charte pour réformer la constitution et la citoyenneté. Pour ces auteurs, «birthright» désigne le privilège natif des Anglais, quelle que soit leur fortune. ${ }^{7}$

Dans les deux cas, une vision de l'histoire nationale soutient un discours sur l'ordre social et politique. Un certain usage des notions de droit natif et de conquête permet de répartir et de limiter ce que l'on autorise à chaque groupe social impliqué dans le combat contre la prérogative royale. Il en est question à Putney, mais il en est aussi question chez Winstanley. En revanche, le discours des Niveleurs est un discours très patriotique et partisan. En affirmant leur «birthright,» ils excluent d'autres groupes du partage : les Papistes, les Cavaliers ou les monopolistes. Ils affirment la nécessité d'un suffrage étendu, mais nient le droit de certains à en bénéficier. Le «birthright» est pour eux un droit du sol et un droit du sang. Pour Ireton, cité plus haut, il ne se différenciait pas du droit accordé à l'étranger vivant sur le sol anglais.

Ce qui va distinguer Winstanley dans son traitement de ce problème, c'est l'évolution de son discours vers l'universalisme. Grâce à l'omniprésence du langage de l'Ecriture sainte dans son discours sur le droit, les deux lignages, le normand et l'anglo-saxon, vont symboliser deux tendances dans l'homme et dans l'espèce humaine en général. Un discours pouvant aller jusqu'au sectarisme politique va être subverti en langage d'amour universel. En dépassant la revendication purement politique pour révéler un message eschatologique, Winstanley fait des pauvres opprimés d'Angleterre les représentants d'une humanité à vocation christique.

\section{"Birthright," mythe normand et typologie chez Winstanley}

Le mythe normand est présent dans presque tous les écrits de Winstanley, et il y prend une valeur plus ou moins symbolique selon les phases de la lutte des Diggers. Si ses premières revendications utilisent le mythe dans un sens juridique proche de celui de Lilburne, Winstanley en perçoit très vite les potentialités conservatrices et ses démêlés avec les juges et «lords of the manor» lui montrent combien le pouvoir du Parlement et de l'Armée Nouveau Modèle soutient les mêmes divisions sociales que la prérogative royale pour laquelle le peuple a soutenu la «gentry» dans la guerre civile.

L'originalité de la version du mythe normand que proposait Winstanley, est que des premiers écrits aux derniers, il est lié indissociablement au mythe de Jacob et Esaü.

Dans le premier chapitre de The Law of Freedom (1651), le paradigme de l'usurpation est précisément explicité.

When William Duke of Normandy had conquered England, he took possession of the earth for his freedom and disposed of our English ground to his friends as he pleased, and made the conquered English his servants, 
to plant the earth for him and his friends.

And all kings, from his time to King Charles, were successors of that conquest ; and all laws were made to confirm that conquest.

For there are his old laws and statutes yet to be read, that do show how he allowed the conquered English but three pence and four pence a day for their work, to buy them bread of their task-masters ; but the freedom of the earth he and his friends kept in their own hands.

And as kings, so the old gentry and the new gentry likewise, walking in the same steps, are but the successors of the Norman victory. 8

Les inégalités civiques viennent de la même cause, selon The True Levellers' Standard Advanced (1649):

For when any trustee or state officer is to be chosen the freeholders or landlords must be the choosers, who are the Norman common soldiers, spread abroad in the land. And who must be chosen but some very rich man, who is the successor of the Norman colonels or high officers? And to what end have they been thus chosen but to establish that Norman power the more forcibly over the enslaved English, and to beat them down again whereas they gather heart to seek for liberty??

Ces passages donnent l'impression qu'une fatalité à caractère purement ethnique interdit toute mobilité sociale et bloque tout accès des pauvres d'Angleterre à la citoyenneté, comme s'il s'agissait de la situation de la population catholique d'Ulster il y a cinquante ans. Le type de tenures imposé par la conquête est bien sûr exposé selon le même principe, et les enclosures sont même avancées au onzième siècle, car c'est elles qui sont l'apanage des «freeholders,» face aux pauvres qui doivent lutter pour avoir le droit de cultiver les «commons» qui sont leur «birthright.»

Les héritiers symboliques des Normands ne doivent pas perdre de vue que l'Angleterre est en révolution, qu'elle a mis à bas le pouvoir royal qui était le composant essentiel du système d'oppression, que les pauvres ont aidé la «gentry» à gagner ce combat au nom de la Solemn League and Covenant de septembre 1643 , dont les promesses de libération ne sont pas encore tenues. Il reste encore du chemin à faire pour que la «gentry» s'acquitte de sa promesse envers ses partenaires plus pauvres, mais on peut douter qu'elle ait jamais eu conscience de s'engager à quoi que ce soit envers quiconque d'extérieur à elle-même, ce qui peut expliquer l'incompréhension à laquelle Winstanley était confronté lorsqu'il tenait des propos comme ceux-ci :

Take notice that England is not a free people till the poor that have no land have a free allowance to dig and labour the commons, and so live as comfortably as the landlords that live in their enclosures. For the people have not laid out their monies and shed their blood that their landlords the Norman power, should still have its liberty and freedom to rule in tyranny in his lords, landlords, judges, justices, bailiffs and state servants ; but that the oppressed might be set free, (...) and the poor peo- 
ple's hearts comforted by an universal consent of making the earth a common treasury, that they may live together as one house of Israel, united in brotherly love into one spirit ; and having a comfortable livelihood in the community of one earth, their mother. ${ }^{10}$

Toutefois, les conditions de cette émancipation universelle des Anglais, qui doit précéder celle de tous les autres peuples, ne sont pas toujours nettes dans le discours de Winstanley. Il peut s'agir de la prise de conscience par les Normands de la nécessité spirituelle de la cession aux plus pauvres de leur droit sur les «commons» pour que soit réalisée la promesse du Covenant, mais le ton apocalyptique de certains textes plus tardifs, comme New Year's Gift (janvier 1649/50) laisse entendre que des cataclysmes menacent ceux qui ne se laisseront pas pénétrer par l'esprit du Christ revenu en esprit dans chaque individu.

Now England is the first of nations that is upon the point of reforming : and if England must be the tenth part of the city Babylon that falls off from the Beast first, and would have that honour, he must cheerfully (...) cast out kingly covetous property, and set the crown upon Christ's head, who is the universal love of free community, and so be the leader of that happy restoration to all the nations of the world. And if England refuse, some other nation may be chosen before him, and England then shall lose his crown (...). ${ }^{11}$

Les modalités de la réorganisation de la société et de l'Etat sont détaillées dans The Law of Freedom, mais ce n'est pas mon objet ici. La question de l'identité implique celle des fondements, non celle des moyens ou des effets, et c'est pourquoi il convient maintenant de considérer le langage biblique qui accompagne ce discours sur l'usurpation normande. Winstanley incorpore le mythe normand à la typologie qui relie Adam, Caïn, Esaü, Saül et Judas.

Dès ses premiers écrits, en effet, Winstanley explore le thème de la vocation christique du peuple anglais. Le thème n'est pas nouveau, et l'on connaît le Book of Martyrs de Foxe, et les déclarations de Cromwell et de ses prédicateurs, qui font de l'Angleterre le Nouvel Israël. Ce qui est nouveau chez Winstanley, c'est la localisation de cette vocation dans la section la plus humble du peuple anglais. Fort de la préférence du Christ pour les plus pauvres, il accorde le privilège de la vocation rédemptrice aux humbles, qui doivent avoir accès aux «commons» pour vivre. Le petit reste saint, le «blessed remnant,» devient chez lui la masse des plus pauvres.

Le mythe adamique est l'un des plus débattus et des plus rebattus de la période. On le trouve sous la plume des rois Stuart comme sous celle de Filmer dans Patriarcha ou de son critique John Locke. Chez Filmer comme chez Locke, la chute n'est pas ou peu prise en compte. L'important est l'héritage. Dieu donne à Adam et à ses héritiers la souveraineté sur la création. Pour Filmer, dans son interprétation patriarcaliste, c'est le fondement 
du droit divin des monarques, car Adam était père et les monarques sont les descendants des premiers souverains, qui étaient des patriarches. Pour Locke, plus tard, ce droit dérivé d'Adam s'applique à tous les hommes, qui dans l'état de nature ont un droit imprescriptible aux biens qu'ils ont acquis par leur travail. Pour Winstanley, en revanche, Adam est A-dam, pour jouer sur le mot «dam,» barrage, ${ }^{12}$ ou pour suggérer, par l'étymologie, ${ }^{13}$ qu'Adam, pétri avec de la terre, est celui qui par sa chute, due à l'esprit de «covetousness,» a éloigné ses héritiers de leur droit sur la libre jouissance de la terre.

In the beginning of time, the great creator reason made the earth to be a common treasury, to preserve beasts, birds, fishes and man, the lord that was to govern this creation ; for man had domination given to him, over the beasts, birds and fishes; but not one word was spoken in the beginning that one branch of mankind should rule over another. ${ }^{14}$

Dès les premiers mots du True Levellers' Standard Advanced, deux aspects essentiels du thème adamique chez Winstanley sont posés : la seigneurie de l'homme sur tous les êtres, et le caractère absolu de ce don, qui est fait à toute l'espèce humaine, et non à une de ses fractions seulement, qu'elle soit nationale (les Normands) ou sociale (la "gentry»). L'autre dimension de ce thème adamique est la chute, due à la chair (thème paulinien):

But since human flesh (that king of beasts) began to delight himself in the objects of the creation, more than in the spirit reason and righteousness, who manifests himself to be the indweller of the five senses (...), then he fell into blindness of heart, and runs abroad for a teacher and a ruler. ${ }^{15}$

L'institution du pouvoir temporel et celle du pouvoir spirituel sont toutes deux des conséquences de la chute, ce qui conduit ailleurs Winstanley à attribuer à Guillaume le Conquérant l'introduction des dîmes. La chute est responsable de la propriété, mais aussi des enclosures, comme il est dit dans le même pamphlet :

And hereupon the earth (which was made to be a common treasury of relief for all, both beasts and men) was hedged into enclosures by the teachers and rulers, and the others were made servants and slaves : and that earth, that is within that creation made a common storehouse for all, is bought and sold and kept in the hands of a few, whereby the great creator is mightily dishonoured, as if he were a respecter of persons $(. ..){ }^{16}$

Un phénomène de l'histoire nationale, les enclosures, est déjà inclus dans la typologie, mais il reste à mettre en parallèle le drame de Jacob, celui des pauvres, qui sont tous les kyounger brothers» dépouillés de leur héritage («birthright») aux dépens d'un frère aîné plus fort et idolâtre. 
And since the coming in of the stoppage, or the A-dam, the earth hath been enclosed and given to the elder brother Esau, or man of flesh, and hath been bought and sold from one to another ; and Jacob, or the younger brother, that is to succeed or come forth next, who is the universal spreading power of righteousness that gives liberty to the whole creation, is made a servant. ${ }^{17}$

Les frères aînés sont les landlords, héritiers des Normands, comme le disent les Diggers dans leur Appeal to the House of Commons (éte [?] 1649) :

(...) the common people, after all their (...) loss of blood to recover England from under the Norman yoke, shall have the freedom to improve the commons and waste lands free to themselves, as freely their own as the enclosures are the property of the elder brotbers. ${ }^{18}$

Le lien typologique entre le mythe normand et la lignée Adam-Esaü est donc clair pour Winstanley. Mais le lien entre la monarchie et les fils jumeaux d'Isaac, qui se battaient dès le ventre maternel est explicité au début de l'utopie de Winstanley, The Law of Freedom :

This kingly governement is he that makes the elder bretbren freemen in the earth, and the younger bretbren slaves in the earth, before they have lost their freedom by transgression to the law.

Nay, he makes one brother a lord and another a servant while they are in their mother's womb, before they have done either good or evil. ${ }^{19}$

Ces divers rapprochements entre le mythe national et la typologie, auxquels je pourrais ajouter des dizaines de pages d'allusions, et d'intertextualité circulaire, situent dans la pensée de Winstanley l'originalité de la position de l'Angleterre, et singulièrement de ses pauvres, dans le plan de Dieu qui est en train de ramener l'humanité à ses desseins. Etre Anglais, c'est être privilégié car Dieu a choisi l'Angleterre pour être la première nation rachetée, comme le montre la chute du roi, abattu par le combat de la kgentry» et des «commoners» contre l'héritier de Guillaume le Conquérant. Etre pauvre, c'est en plus appartenir au groupe de ceux que le Christ, «the great Leveller,» dans les termes du New Year's Gift, a explicitement décrits comme étant ses représentants, le sel de la terre, ceux que les disciples auraient toujours avec eux. C'est en eux, les frères cadets, que se réalise la prophétie de Daniel et de l'A pocalypse, par eux que la grande restauration du règne de la «righteousness» va s'opérer.

\section{Le paradigme de la restauration}

Le sous-titre de The Law of Freedom est True Magistracy Restored, c'està-dire la restauration de la légitimité véritable, si je me permets d'interpréter le concept de «magistracy» dans un sens qui me semble essentiel 
chez Winstanley. Il est évident que le thème de la restauration chez cet auteur n'a rien à voir avec ce que redouteront dix ans plus tard Milton et Harrington après la chute de Richard Cromwell. Lorsque le travail de la prophétie est accompli, il semble que celle-ci doive faire place à la démonstration des moyens qui vont permettre de faire passer dans les faits le désir de restauration. Le terme qui a traversé les années de la guerre civile, de la république et du Protectorat est celui de «reformation» ; Winstanley s'y réfère beaucoup lorsqu'il veut réveiller chez les chefs puritains les promesses des «Covenants» et des «Engagements.» ${ }^{20} \mathrm{Si}$ je poursuis toutefois mon idée du rétablissement dans ses droits du frère cadet aux dépens du frère aîné indigne et usurpateur, c'est bien de la restauration de valeurs fondamentales qu'il s'agit.

Comme je l'ai dit plus haut, il existe chez Winstanley une folle espérance de voir les frères aînés céder leur «birthright» (au sens d'héritage) pour que soit restaurée la primogéniture spirituelle des frères cadets. Les moyens historiques et politiques de faire advenir cet événement ne sont pas évoqués, tout au plus peut-on envisager les écrits-mêmes des Diggers comme des moyens de persuasion à l'usage des pouvoirs en place. Ces écrits ne cherchent pas directement à attirer l'attention des plus pauvres, si l'on excepte (peut-être) les appendices dans lesquels les épreuves subies par les Diggers sont énumérées. ${ }^{21} \mathrm{Je}$ crois pouvoir y discerner de la part de Winstanley la volonté de convaincre en premier lieu ceux qui monopolisent les terres, les héritiers des officiers et des soldats normands.

L'Angleterre est présentée par le chef de file des Diggers comme un nouvel Israël, ${ }^{22}$ dont les pauvres sont le Jacob et le Christ. C'est dans ce pays que se réalise le «Second Coming,» c'est la première tombée des cornes de la bête, celle qui va ouvrir la voie au monde. Le discours de Winstanley est donc universaliste alors qu'il s'appuie sur un mode de pensée dualiste, qui pourrait à tout moment exprimer le sectarisme social, confessionnel ou national. Le mythe du Joug Normand est un mythe séparateur, qui oppose des lignages nationaux, ce qui pourrait s'avérer dangereux entre les mains de démagogues, et ce d'autant plus que ces lignages sont fictifs. Le fait de rajouter à cette division ethnique une division sociale pourrait accroître les effets pervers d'un discours que les politologues d'aujourd'hui qualifieraient d'identitaire. Il reprend à son compte le ton prophétique de Jérémie dans son Watch-Word to the City of London, and the Army d'août 1649, lorsqu'il apostrophe la Cité et l'Angleterre, et les exhorte à abandonner l'assoupissement babylonien pour suivre l'agneau :

O thou City, thou hy pocritical City! Thou blindfold drowsy England, that sleeps and snorts in the bed of covetousness, awake, a wake, the enemy is upon thy back, he is ready to scale the walls and enter possession, and wilt thou not look out? (...)

I tell thee, thou England, thy battles now are all spiritual, dragon against the Lamb, and the power of love against the power of covetousness ; 
therefore all that will be soldiers for Christ, the law of righteousness, join the Lamb. ${ }^{23}$

Comment ne pas penser au «mental fight» de William Blake? Ce n'est pas à la guerre des classes, ni à la lutte des lignages que Winstanley appelle ses contemporains, mais à des batailles spirituelles. Il leur faut quitter Babylone pour rejoindre l'Israël spirituel, l'anti-type de l'Israël historique où il n'y avait pas de mendiants :

For in this work of restoration there will be no beggar in Israel. For surely, if there was no beggar in literal Israel, there shall be no beggar in spiritual Israel the anti-type, much more. ${ }^{24}$

Si Winstanley ne peut être accusé d'intolérance ou de sectarisme, c'est qu'il est inspiré par un christianisme ayant opté pour la résurrection de tous. L'esprit du Christ revenant dans tous ses enfants est le premier moment de la fin des temps. Le Retour du Christ est en train de s'opérer, et il faut collaborer avec l'esprit. C'est cette dimension chrétienne qui me fait hésiter devant les rapprochements fréquents entre Winstanley et le communisme des $19^{\mathrm{e}}$ et $20^{\mathrm{e}}$ siècles. Il ne s'agit pas d'une action violente, mais d'une participation spirituelle, pacifique à un mouvement qui n'est pas mené par la violence historique, mais par la puissance justicière et aimante de l'Esprit. Il ne prétend pas toucher à la propriété de ceux qui possèdent des biens, car il comprend la notion de possession, mais il veut affirmer le droit des dépossédés au partage des «commons.» En tant que chrétiens anglais, nés libres bien que pauvres, car héritiers symboliques des AngloSaxons nés libres, ils doivent affirmer la liberté de tous. Ils transcendent le discours identitaire pour affirmer l'universalité des bienfaits de Dieu créateur, le «Créateur Raison.»

Il se dégage de ce parcours à travers l'oeuvre de Winstanley une image particulière de sa conception de l'identité collective des pauvres d'Angleterre, «the poor oppressed people of England.» Ils sont pris dans l'enchevêtrement de plusieurs réseaux mythologiques. Le premier réseau mythique est celui du Joug Normand, le second celui de la Grande Charte, le troisième celui qui oppose Jacob et Esaü, qui n'est autre qu'un avatar de l'opposition entre Sion et Babylone. Le travail, au sens obstétrique, de la révolution à laquelle participent ces pauvres, doit conduire à la réalisation de la promesse rédemptrice dans la société anglaise, et peut-être, par elle, dans le monde entier. Le Christ est déjà revenu, il est présent en l'esprit chez les «younger brothers» d'Angleterre, et il les porte à rétablir leur position d'aînés réels et d'élus, de premiers conçus et de premiers occupants.

On pourrait s'étonner, avec un regard historique critique, de ne pas voir mentionner les premiers occupants celtes expulsés de leurs terres par les envahisseurs germaniques et scandinaves, et les premiers occupants expulsés par les Celtes. Mais nous sommes dans un exercice de mythographie eschatologique. La fiction du mythe politique soutient l'action d'un groupe 
dont elle justifie les droits et la légitimité, en s'appuyant sur un paradigme eschatologique qui garantit l'inévitabilité de la victoire dans un temps qui est présenté comme étant le présent. ${ }^{25}$

Les rapports entre le mythe politique et l'utopie ont souvent été débattus. Deux ans après l'aventure de Saint-George's Hill, c'est-à-dire en 1651, Winstanley publie un modèle complet de gouvernement précédé d'un résumé de ses écrits mythographiques antérieurs, et qu'il intitule The Law of Freedom, or True Magistracy Restored. Bien que ce texte ne soit pas une fiction narrative comme les utopies de More, Bacon, Campanella, ou même de Harrington, les caractéristiques du programme constitutionnel de restauration du «birthright» des frères cadets sont empreintes de l'esprit de l'utopie : collectivisation, existence de conseils à tous les niveaux de division du territoire. Après l'échec du mouvement eschatologique, la structuration de l'utopie, l'invention de superstructures (pour reprendre le terme de.... James Harrington) fige le dynamisme des débuts.

Tant d'utopies sont des modèles dynamiques, des idéaux en marche, qu'on est contraint de constater le caractère pessimiste de cette utopie écrite à la fin de l'oeuvre et après l'action. La force utopique de l'oeuvre de Winstanley résidait dans le mythe et dans l'impulsion d'un groupe en mouvement. Dès qu'il s'agit de convaincre de la force du mythe agissant, alors que l'action n'est plus là pour alimenter l'écriture, la clôture de l'utopie semble agir comme un éteignoir.

Luc Borot

Université Paul-Valéry (Montpellier III) Communication présentée au Congrès de la SAES, Aix-en-Provence, mai 1991. 


\section{Notes}

1 Voir Olivier Lutaud, Gerrard Winstanley, christianisme et socialisme sous Cromwell (Paris : Didier, 1976), Chr. Hill, The World Turned Upside-Down (Harmondsworth : Pelican Books, 1975), «The Religion of Gerrard Winstanley,» Past \& Present, suppl. 5 (Oxford, 1978) et «Religion and Politics,» Collected Essays, 2 vols. (Plymouth : The Harvester Press, 1986) 2 : 185-252.

2 Les écrits de Winstanley se trouvent principalement dans trois éditions : ed. G.H. Sabine, The Works of Gerrard Winstanley (Ithaca, N.Y. : Cornell UP, 1941) ; ed. L.D. Hamilton, Selections from Winstanley (London: The Cresset Press, 1944 ) ; ed. Chr. Hill, 'The Law of Freedom' and Other Writings, 2nd ed. (The Past and Present Society : Cambridge UP, 1983) ; je cite comme Hill, Law..., suivi du titre du pamphlet en abrégé.

3 Les débats sont reproduits dans A.S.P. ed. Woodhouse, Puritanism and Liberty, being the Army Debates (1647-1649) from the Clarke Manuscripts (London: Dent, Everyman, 1938-1986) 53.

4 Ed. Woodhouse 54.

5 Voir Armand Abécassis, La Pensée juive, vol. 1, «Du Désert au désir» (Paris : Livre de Poche «Essais,» 1987), $1^{\text {re }}$ partie, ch. 1, surtout 26, 34-36, 45-51. Un exemple d'analyse rabbinique se trouve dans Rabbi Jacob ben Isaac Achkenazi de Janov, Le Commentaire de la Torab "Tseenab Ureenab" (Hanau, 1622), trad. du Yiddish par Jean Baumgarten, Lagrasse, Verdier, coll. Les Dix Paroles, 1987, ch. Genèse, section Toledot, 179-98.

6 Sir Edward Coke, The Compleate Copybolder (London, 1641) section 31. En précisant que les kLords of manors, qui étaient à l'origine tous barons, siégeaient *in the upper house,» Coke présuppose qu'il y avait deux chambres ; lorsqu'il ajoute qu'avec le temps, vu la dégradation des «manors,» seuls ceux que le roi jugeait dignes eurent le droit de siéger, «such as the King (...) thought good to call by writ,» il fait allusion à l'article de la Magna Carta sur les \&writs of summons» qui n'étaient pas les mêmes pour les *Lords temporal and spiritual* et pour illi qui in capite tenent de nobis, qui sont les futurs représentants des bourgs et des comtés.

7 Ce débat est analysé dans William Haller, Liberty and Reformation in the Puritan Revolution (N.Y. : Columbia UP, 1955) ch. 8, surtout 274-82. Les textes concernés sont dans eds William Haller and G. Davies, The Leveller Tracts 1647-1653 (Gloucester, Mass. : Peter Smith, 1964) ou dans ed. G.E. Aylmer The Levellers in the English Revolution (London : Thames and Hudson, 1975).

8 Ed. Hill, $L F 297$.

9 Ed. Hill, TLSA 86.

10 Ed. Hill, TLSA 87.

11 Ed. Hill, NYG 198. Une version plus pacifique est dans Poor Oppressed People of Englaind, ed. Hill 103. 
12 «This coming in of bondage is called A-dam, because this ruling and teaching power without doth dam up the spirit of peace and liberty...» (ed. Hill, TLSA 78).

13 En hébreu, âdamâh veut dire «sol.»

14 Ed. Hill, TLSA 77.

$15 \quad$ Ed. Hill TLSA 77.

16 Ed. Hill, TLSA 78.

17 Ed. Hill, TLSA 79.

18 Ed. Hill, $A H C$ 112. C'est moi qui souligne.

19 Ed. Hill, $L F 307$.

20 Ed. Hill, «Poor Oppressed People of England» 105, pour l'une des nombreuses mentions de la Solemn League and Covenant du 25 septembre 1643.

21 Ed. Hill, NYG 205-07, par exemple.

22 Ed. Hill, NYG 208 ; v. aussi TLSA cité infra.

23 Ed. Hill, WCLA 148.

24 Ed. Hill, TLSA 91.

25 Voir Hill, «The Norman Yoke,» sur le mythe arthurien comme mythe royaliste. 